\title{
25 Research Soure \\ Bioethanol Production from Sugarcane Molasses by Engineered Strain Lactobacillus Casei E1
}

\section{Song Wang ( $\nabla$ ws_1984@163.com )}

Northeast Agricultural University https://orcid.org/0000-0002-3710-8213

\section{Ran Tian}

Northeast Agricultural University

\section{Buwei Liu}

Northeast Agricultural University

Hongcai Wang

Northeast Agricultural University

Jun Liu

Northeast Agricultural University

Chenghui Li

Northeast Agricultural University

Mingyue Li

Northeast Agricultural University

Smith Etareri Evivie

University of Benin Faculty of Agriculture

Bailiang Li

Northeast Agricultural University

\section{Research Article}

Keywords: Sugarcane molasses, Lactobacillus casei , Bioethanol, Fermentation

Posted Date: February 18th, 2021

DOl: https://doi.org/10.21203/rs.3.rs-207976/v1

License: (c) (i) This work is licensed under a Creative Commons Attribution 4.0 International License.

Read Full License 


\section{Abstract}

Sugarcane molasses are considered a potential source for bioethanol's commercial production because of its availability and low market price. It contains high concentrations of fermentable sugars that can be directly metabolized by microbial Fermentation. Lactic acid bacteria, especially Lactobacillus casei, have a high potential to be a biocatalyst in ethanol production that they are characterized by strong abilities of carbohydrate metabolism, ethanol synthesis, and high alcohol tolerance. This study aimed to evaluate the feasibility of producing ethanol from sugarcane molasses by Lactobacillus casei used engineering strain $L$. casei $\mathrm{E} 1$ as a starter culture. The effects of environmental factors on the metabolism of $L$. casei E1 were analyzed by high-performance liquid chromatography (HPLC) system, and the gene expression of key enzymes in carbon source metabolism was detected using quantitative real-time PCR (RT-qPCR). Results showed that the strain could grow well, ferment sugar quickly and produce high yielded ethanol in cane molasses. By fermenting this bacterium anaerobically at $37^{\circ} \mathrm{C}$ for $36 \mathrm{~h}$ incubation in $5^{\circ} \mathrm{BX}$ molasses when the fermenter's $\mathrm{pH}$ was controlled at 6.0, ethanol yield reached $13.77 \mathrm{~g} / \mathrm{L}$, and carbohydrate utilization percentage was $78.60 \%$. RT-qPCR results verified the strain preferentially ferment glucose and fructose of molasses to ethanol at the molecular level. In addition, the metabolism of sugars, especially fructose, would be inhibited by elevating acidity. Our findings support the theoretical basis for exploring Lactic acid bacteria as a starter culture for converting sugarcane molasses into ethanol.

\section{Key Points}

1. Verificating the ability of engineering strain L. casei E1 to produce bioethanol.

2. The possibility of lactic acid bacteria as a starter culture for ethanol production.

3. Carbohydrate metabolic characteristics of the strain in sugarcane molasses.

\section{Introduction}

There has been a global increase in the demand for alternate renewable energy. Bioethanol, which can serve as a gasoline additive to increase octane and improve vehicle emissions in its pure form (Baki et al. 2020), is an alcohol made by microorganisms through the Fermentation of carbohydrates. At present, bioethanol can be derived from cellulosic biomass such as trees and grasses, which are non-food sources. However, cellulose and hemicellulose of fibrous biomass are difficult to convert into fermentable sugars for direct use by microorganisms to produce ethanol. Moreover, the sugar produced by the hydrolysis of raw materials cannot be fermented directly, which affects the yield of alcohol. Also, phenols, aldehydes, acids, and other organic substances produced during pretreatment and hydrolysis may inhibit Fermentation and have toxic effects on the biocatalytic host (Tanawut et al. 2020). This results in low efficiency and the need to integrate additional removal and recovery processes during Fermentation. 
Sugarcane molasses is a subsidiary product of the sugar industry, containing high concentrations of fermentable sugars (sucrose, glucose, and fructose), protein, vitamins, and trace elements that can be directly metabolized by microbial Fermentation. Thus, it doesn't require additional operations that significantly increase the cost of biosyntheses such as chemical hydrolysis or enzymatic hydrolysis (Dziugan et al. 2013). Saccharomycetes is the biocatalyst of ethanol produced by sugarcane molasses. However, Yeast's optimum fermentative $\mathrm{pH}$ is $4.0-4.5$ while sugarcane molasses are about 6.2(Wu et al. 2020). Therefore, a large amount of sulfuric acid should be added to reduce the acidity when diluting. After the acidification and clarification treatment, the fermentation speed will be slower without clarification. Moreover, the addition of a large amount of sulfuric acid also increases the production cost of molasses ethanol.

Lactic acid bacteria (LAB) are facultative anaerobic gram-positive bacterium that produces lactic acid as the primary end-product of carbohydrate fermentation. It can tolerate high acidity and high concentrations of alcohol (Davis et al. 1988; Britz and Tracey 1990; Edwards and Jensen, 1992; Gold et al. 1992; G-Alegría et al. 2004; Takashi et al. 2016). Some lactic acid bacteria strains, such as Lactobacillus mucosae, Lactobacillus amylovorus, Pedioccus parvulus, Lactobacillus crispatus, and Weissella, which can survive and grow in 3 to $4 \%$ butanol, were found (Liu et al. 2012). Leuconostoc mesenteroides was added to wine fermentation agents to enhance the flavor of alcohol. The strain was observed to be growing well under a condition of $12 \%$ alcohol content and pH 3.4 (Yao et al. 2011). These results indicated that $L A B$ could adapt well to the alcohol environment and resist higher alcohol content. Among LAB, lactobacilli display the highest alcohol tolerance.

Lactobacillus casei, one species of lactobacilli that has been widely used in the food industry over decades, grows well in carbohydrate-rich environments and converts diverse substrates to organic acids ethanol. It is characterized by strong abilities of carbohydrate metabolism (Koryszewska-Bagińska et al. 2019) and a wide range of substrate utilization such as monosaccharides, disaccharides, various oligosaccharides, and polysaccharides. It has been proved that Lactobacillus casei isolated from plant materials and the human gastrointestinal tract can utilize pentose and some penta- and hexasaccharides (Cai et al. 2007; Suzuki et al. 2020). Lactobacillus casei can metabolize and synthesize ethanol through the Embden Meyerhof Parnas (EMP) pathway, and some strains can also produce ethanol through heterogeneous fermentation Entner-Doudoroff (ED) pathways. The study by London et al. confirmed that L. casei could produce carbonose-5-phosphate through the intermediate product ribonose-5-phosphate in the pentose phosphate pathway. The acetophosphate, formed by pyruvate kinase catalysis of carbonose5-phosphate and pyruvate, is converted to ethanol by acetyl-transacetylation and dehydrogenation (London and Chace 1979). More importantly, L. casei boasts of several relatively simple metabolism pathways (Xin et al. 2018) and genetic advantages, including the availability of genome sequences, genome-scale metabolic models and methods for integration of foreign DNA (Blanco-Míguez et al. 2019; Welker et al. 2015; McAuliffe et al. 2019). These attributes suggest that Lactobacillus casei has a high potential to be a biocatalyst in ethanol production. 
The growth and metabolism of strains are affected by many factors such as carbon, nitrogen, temperature, $\mathrm{pH}$, and oxygen (Meng et al. 2019). The dilution of the natural substrate is directly related to the concentration of each component of the medium. Excessive concentration of the natural substrate leads to high concentrations of carbohydrates, which will increase osmotic pressure that changes or destroys the abilities of strains to transport and metabolic each component (Bubnová et al. 2014). In environments with different oxygen content, since the metabolic pathways of strains change, aerobic and anaerobic Fermentation will affect types and yields of products (Dittrich et al. 2005; Wushke et al. 2017; Matsuoka and Kurata 2017). L. casei synthesizes various organic acids such as pyruvate, lactic acid, acetic acid, and succinic acid to metabolize carbohydrates to produce ethanol (Vinay-Lara et al. 2016). Fermentation progresses, organic acids that can increase the acidity of fermentation liquid gradually accumulate. The dramatic change in $\mathrm{pH}$ will affect the carbohydrate metabolism of strains because high acidity will cause metabolic-related components on the cell membrane, such as channel proteins, transport proteins, and signal pathway proteins, to lose their normal function (Virgilio et al. 2017).

According to the preliminary results, $L$. case $i$ is an aerotolerant strain that can grow under aerobic and anaerobic conditions. Its optimum fermentation temperature is $37^{\circ} \mathrm{C}$. The optimum $\mathrm{pH}$ values in allpurpose tween (APT) medium (Difco ${ }^{\mathrm{TM}} \mathrm{BD}$ ), de Man, Rogosa, and Sharpe (MRS) medium, and straw hydrolysate were 6.0 (Vinay-Lara et al. 2016). According to the comparative genomics analysis of metabolic pathways of $L$. casei $12 \mathrm{~A}$, it was found that $L$. casei $12 \mathrm{~A}$ has a strong ability to metabolize carbohydrates as well as convert them into bioethanol (Wang et al. 2015). L. casei E/ was engineered to produce ethanol instead of lactate as its major end-product from carbohydrates (Vinay-Lara et al. 2016).

To explore the effects of environmental factors on the metabolism of L. casei El, the impact of different concentrations of sugarcane molasses solution on the living cell number, and the carbohydrates utilization and product synthesis abilities of the strain under different conditions were analyzed through the determination of the types and yields of carbohydrates in sugarcane molasses fermentation liquid using the high-performance liquid chromatography (HPLC) system. Quantitative real-time PCR (RT-qPCR) was used to analyze the expression level of the key enzyme genes of carbohydrate metabolism and investigate the effect of pH change on the strain's carbohydrate metabolism. This paper aims to lend theoretical and technical support for the industrial production of molasses ethanol.

\section{Materials And Methods}

\section{Preparation of sugarcane molasses solution}

The fresh sugarcane molasses, whose initial liquid concentration is $80^{\circ} \mathrm{Bx}$, was diluted to $40^{\circ} \mathrm{Bx}, 30^{\circ} \mathrm{Bx}$, $20^{\circ} \mathrm{Bx}, 10^{\circ} \mathrm{Bx}, 7.5^{\circ} \mathrm{Bx}$, and $5^{\circ} \mathrm{Bx}$, respectively, using deionized water. To ensure sufficient nitrogen sources in the fermentation solution, $5 \mathrm{~g} / \mathrm{L}$ of yeast extract, $5 \mathrm{~g} / \mathrm{L}$ of peptone, and $10 \mathrm{~g} / \mathrm{L}$ of beef extract were added to various molasses concentrations according to the MRS basic medium formula. Then the $\mathrm{pH}$ value was adjusted to 6.0 . 


\section{Construction of L. casei E1}

The engineered L. casei E1, a derivative of wild strain L. casei 12A (GenBank: CP006690.1) lacking Idh1, was constructed using the procedure described by Broadbent et al. (2003). Briefly, a synthetic production of ethanol (PET) cassette encoding the Zymomonas mobilis pyruvate decarboxylase (PDC) and alcohol dehydrogenase (ADHII) genes under the control of the native $L$. casei $12 \mathrm{~A}$ phosphoglycerate mutase (pgm) promoter (L. casei 12A $\Delta / d h 1$ ::Ppgm-PET) was assembled and codon-optimized using Java Codon Adaptation Tool and inserted into the 12A /dh1 locus (Vinay-Lara et al. 2016).

\section{Detection of carbohydrate metabolic characteristics}

The utilization of carbohydrates and production of metabolic end-products were detected by the HPLC system, including Waters Alliance 2695 Spectrometer, Waters 2414 Refractive Index Detector (RID), and Aminex HPX-87H (300mm $\times 7.8 \mathrm{~mm}$ ID, $9 \mu \mathrm{m}$, Bio-Rad Labors) chromatographic separation column under $5-\mathrm{mmol} / \mathrm{L}$ sulfuric acid solution of the mobile phase, $30^{\circ} \mathrm{C}$ of column temperature, and $0.6 \mathrm{~mL} / \mathrm{min}$ of flow rate.

\section{Culture of L. casei E1}

The working culture of $L$. casei E1 was prepared from a frozen stock using two sequential transfers $(0.1 \%$ inoculum) that the strain incubated in MRS medium statically at $37^{\circ} \mathrm{C}$ for $24 \mathrm{~h}$ and cultured in $10^{\circ} \mathrm{Bx}$ of sugarcane molasses solution at $37^{\circ} \mathrm{C}$ for $30 \mathrm{~h}$. Then the bacterial liquid was transferred into different concentrations of sugarcane molasses solutions, respectively, with the initial concentration of $10^{7}$ $\mathrm{CFU} / \mathrm{mL}$. The strain's living cell number was determined at $0,8,12,24,30,36,48$, and $60 \mathrm{~h}$ on MRS solid medium.

\section{Effects of oxygen on ethanol production}

The strain was cultured in two bioreactors with the same molasses solution under anaerobic (20 psi, $\mathrm{CO}_{2} / \mathrm{N}_{2}$ ) and aerobic conditions, respectively, at $33^{\circ} \mathrm{C}$ for $72 \mathrm{~h}$. The liquid fermentation samples were determined at $0,4,8,12,16,24,30,36,48$, and $72 \mathrm{~h}$ by High-Performance Liquid Chromatography (HPLC).

\section{Effects of pH on growth and metabolism}

One of the fermenters' pH value was controlled by the Bioreactor control system pumping in $6 \mathrm{~mol} / \mathrm{L}$ of $\mathrm{NaOH}$ and $6 \mathrm{~mol} / \mathrm{L}$ of $\mathrm{HCl}$. The $\mathrm{pH}$ electrode recorded the acidity of the unregulated fermentation broth. The fermentation broth was collected at $0,4,8,12,16,24,30,36,48$, and $60 \mathrm{~h}$ for further analysis. 
Effects of $\mathrm{pH}$ on expression of key enzyme genes of carbon source metabolism during transformation

The absolute gene expressions of glucokinase (GK, EC 2.7.1.2), invertase (INV, EC 3.2.1.26), and phosphofructokinase (PFK, EC 2.7.1.56) were detected through the real-time fluorescence quantitative PCR (RT-PCR) during Fermentation. The primers utilized in this study have been described in Table 1. Working cultures were prepared from the frozen storage of liquid nitrogen. DNA was extracted using the Ezup column, a bacterial genomic DNA extraction kit (SK8255). Purpose genes were recovered using a columnar DNA adhesive recovery kit (SK8131 Sangon). Connected products were transformed using the one-step rapid receptor cell preparation kit (SK9307 Sangon). The plasmid DNA was extracted using the SanPrep column plasmid DNA small amount extraction kit (SK8191 Sangon), and the RT-PCR detection was operated using ABI SybrGreen PCR Master Mix $(2 \times)$ kit.

\section{Operational formula}

Carbohydrate consumption $(\mathrm{g} / \mathrm{L})=$ Initial carbohydrate content $(\mathrm{g} / \mathrm{L})$ - Residual carbohydrate content $(\mathrm{g} / \mathrm{L})$

Carbohydrate utilization ratio $(\mathrm{w} / \mathrm{w} \%)=\frac{\text { Carbohydrate consumption }(\mathrm{g} / \mathrm{L})}{\text { Initial carbohydrate content }(\mathrm{g} / \mathrm{L})} \times 100 \%$

Ethanol production ratio $(\mathrm{w} / \mathrm{w} \%)=$

Ethanol yield $(\mathrm{g} / \mathrm{L})$

Carbohydrate consumption $(\mathrm{g} / \mathrm{L})$

\section{Statistical analyses}

All experiments were performed at least three independent times and values are expressed as mean \pm standard deviation (SD). In order to compute the relative fold changes in gene expression of the studied genes, datas were analysed using the comparative $2^{-\Delta \Delta C t}$ method was used (Livak andSchmittgen 2001).

\section{Results}

\section{Effects of molasses concentration on the growth of the strain}

As shown in Fig 1, the growth curves of $L$. casei E1 in different concentrations of cane molasses are very similar among the four low concentrations of $5^{\circ} \mathrm{Bx}, 7.5^{\circ} \mathrm{Bx}, 10^{\circ} \mathrm{Bx}$, and $20^{\circ} \mathrm{Bx}$. After about $30 \mathrm{~h}$ of 
Fermentation, the colony number reached the maximum value of $10^{11} \mathrm{CFU} / \mathrm{mL}$, and the growth rate was significantly higher than those in the other two high concentration mediums $\left(30^{\circ} \mathrm{Bx}\right.$ and $\left.40^{\circ} \mathrm{Bx}\right)$. Although the maximum number of living cells in $30^{\circ} \mathrm{Bx}$ is $10^{11} \mathrm{CFU} / \mathrm{mL}$, the strain's slow growth resulted in needing $48 \mathrm{~h}$ to achieve this. Meanwhile, the strain did not grow until $48 \mathrm{~h}$ at $40^{\circ} \mathrm{Bx}$.

\section{Effects of molasses concentration on the metabolism of strain}

It can be seen from Fig 2 that strain E1 first metabolized glucose and fructose and then sucrose; the higher the concentration of molasses, the later the sucrose metabolism started. As shown in Fig $2(a, b)$, at concentrations of $5^{\circ} \mathrm{Bx}$ and $7.5^{\circ} \mathrm{Bx}$, the strain consumed glucose and fructose in about $16 \mathrm{~h}$ while sucrose metabolism began at $12 \mathrm{~h}$. Comparing the two concentrations, the sucrose consumption of the strain was faster at $5^{\circ} \mathrm{Bx}$, which accelerated at $16 \mathrm{~h}$ and slowed down after $36 \mathrm{~h}$. The total sugars' utilization rate was $75.2 \%$ in $5^{\circ} \mathrm{Bx}$ molasses fermented for $72 \mathrm{~h}$ (Tab 1). While in $7.5^{\circ} \mathrm{Bx}$, sucrose consumption slowed down from $16 \mathrm{~h}$ to $28 \mathrm{~h}$ and accelerated after $28 \mathrm{~h}$ (Fig 2a, b). In $10^{\circ} \mathrm{Bx}$ molasses, sucrose consumption was very low at $48 \mathrm{~h}$. In $20^{\circ} \mathrm{Bx}$, only partial glucose and fructose were consumed, and little sucrose was metabolized (Fig 2c, d).

The ethanol production of the strain started earlier in $5^{\circ} \mathrm{Bx}$ and $7.5^{\circ} \mathrm{Bx}$ of low concentrated molasses. As shown in Fig $3(\mathrm{a}, \mathrm{b})$, the strain began producing ethanol from $4 \mathrm{~h}$ in $5^{\circ} \mathrm{Bx}$ and $7.5^{\circ} \mathrm{Bx}$ molasses while ethanol was produced at $12 \mathrm{~h}$ and $16 \mathrm{~h}$ in $10^{\circ} \mathrm{Bx}$ and $20^{\circ} \mathrm{Bx}$ molasses, respectively. The ethanol production rate and yield in $5^{\circ} \mathrm{Bx}$ and $7.5^{\circ} \mathrm{Bx}$ mediums were similar in that the ethanol concentration could reach about $13 \mathrm{~g} / \mathrm{L}$ after $72 \mathrm{~h}$; it was higher than $20^{\circ} \mathrm{Bx}$ molasses in which the yield just reached 7 $\mathrm{g} / \mathrm{L}$ (Tab 2). The highest ethanol yield was up to $38 \%\left(\mathrm{w} / \mathrm{w} \%\right.$ ) in $7.5^{\circ} \mathrm{Bx}$ medium (Tab 1).

With the increase of molasses concentration, the ratio of ethanol to lactic acid production decreased gradually. The ratio of ethanol to lactic acid in the $5^{\circ} \mathrm{Bx}$ fermentation broth was $2.0(\mathrm{mmol} / \mathrm{L}: \mathrm{mmol} / \mathrm{L})$ (Tab 1), the maximum of the four concentrations. In the $20^{\circ} \mathrm{Bx}$ molasses, the ratio was less than 1.0 ( $\mathrm{Tab}$ 1), and a considerable number of carbohydrates were converted into lactic acid by the strain (Tab 1 and Fig 3d).

\section{Effects of oxygen on the ethanol production}

As shown in Fig 4, strain E1 could not synthesize ethanol under aerobic conditions; instead, a small amount of lactic acid was produced. Most of the carbohydrates were used to support the growth of cells. In the anaerobic environment, the strain was in a good growth state, and high ethanol content was obtained in the end product of carbon source metabolism.

\section{Effects of $\mathrm{pH}$ on the ethanol production}


In the unregulated $\mathrm{pH}$ state, the $\mathrm{pH}$ dropped rapidly from 6.0 to 4.5 within $24 \mathrm{~h}$ (Fig 5). Due to the feedback inhibition of lactic acid accumulation on the bacteria's glucose metabolism, the growth and metabolism of strain were affected. After $36 \mathrm{~h}$ of Fermentation, the total sugar utilization was only $66.4 \%$, and the sucrose level remained $10.46 \mathrm{~g} / \mathrm{L}$ after $60 \mathrm{~h}$. Under the condition of $\mathrm{pH}$ control, the growth and metabolism of the strain were exuberant, mainly in three aspects: firstly, the activity of strain was high, and the number of live cells in $36 \mathrm{~h}$ was close to $10^{12} \mathrm{CFU} / \mathrm{mL}$; secondly, the glucose metabolism efficiency was high, and the strain within $60 \mathrm{~h}$ consumed the carbohydrate (Fig 5). The residual carbohydrate content was about $13.03 \mathrm{~g} / \mathrm{L}$ after $36 \mathrm{~h}$ of Fermentation (Tab 3), and sugar utilization rate was approximately $78.6 \%$, which was $12.2 \%$ higher than the unregulated state; finally, the ethanol yield was about $14.85 \mathrm{~g} / \mathrm{L}$ at $60 \mathrm{~h}$, which was about $2.70 \mathrm{~g} / \mathrm{L}$ higher than the unregulated $\mathrm{pH}$ state (Tab 3). Therefore, the regulation of $\mathrm{pH}$ value in the fermentation process at 6.0 is more suitable for the strain to synthesize ethanol by cane molasses fermentation.

Under the condition of regulated $\mathrm{pH}$, the strain entered the growth stability stage from $24 \mathrm{~h}$ and reached the maximum viable amount at $36 \mathrm{~h}$ (Fig 5). The rate of sucrose metabolism by the strain began to decrease after $36 \mathrm{~h}$ of Fermentation (Fig $6 \mathrm{a}$ ), and the increasing rate of ethanol yield was low during the time frame of $36 \mathrm{~h}$ to $60 \mathrm{~h}$, producing only about $1.10 \mathrm{~g} / \mathrm{L}$ ethanol in this $24 \mathrm{~h}$ (Tab 3). Therefore, to reduce production costs and increase production efficiency, the optimum fermentation time for ethanol production is $36 \mathrm{~h}$.

\section{Effects of pH on the gene expression of key enzymes in carbon source metabolism}

The expression level of key enzymes in a duration of $24 \mathrm{~h}$ was selected to evaluate the effect of $\mathrm{pH}$ regulation and control on carbon metabolism. Accordingly, the strain consumed glucose and fructose in 5 ${ }^{\circ} \mathrm{Bx}$ molasses within $24 \mathrm{~h}$, and the $\mathrm{pH}$ value decreased insignificantly after $24 \mathrm{~h}$ of Fermentation (Fig 5). The GK gene expression level increased at first and then reduced under both regulated and unregulated conditions and reached the maximum at $12 \mathrm{~h}$, which was 1.25 and 1.59 times of that at $0 \mathrm{~h}$, respectively (Fig 7a). The INY and GK genes had similar expression levels, but its maximum value appeared at about $8 \mathrm{~h}$, which was 1.17 and 1.54 times of that at $0 \mathrm{~h}$, respectively. Afterward, the INV gene expression level decreased suddenly under the unregulated $\mathrm{pH}$ condition, which is only half the initial value at $16 \mathrm{~h}$ (Fig 7b). The expression level of the PFK gene decreased at first and then increased. The lowest level reached 0.46 and 0.58 times of the initial value under $\mathrm{pH}$ control and non-pH control conditions at $12 \mathrm{~h}$, respectively. Under the condition of control, the expression level of the PFK gene increased significantly at $16 \mathrm{~h}$, which is 1.90 times of the initial level, but suddenly decreased to 0.58 times of the initial level at 24 h (Fig 7c).

The three enzymes' relative gene transcription levels under $\mathrm{pH}$ and non-pH-regulated mediums were reported. Except for INV's gene expression level, which was slightly higher than that of PFK under non-pH control condition at $8 \mathrm{~h}$, all the expression levels of INV under both conditions were lower than those of 
GK and PFK within $24 \mathrm{~h}$ (Fig 8). This verifies that the strain has a metabolism sequence of the three sugars at the molecular level, which is the preferential use of glucose and fructose. All the GK gene expression levels were higher than those of INV and PFK under the condition of non-pH control (Fig 8). Though the expression levels of $\mathrm{GK}$ at $12 \mathrm{~h}$ and $24 \mathrm{~h}$ of non-pH control fermentation were higher than those regulated by $\mathrm{pH}$, the difference between the two fold lines in Fig 7a is small, indicating that the effect of the $\mathrm{pH}$ change on the GK expression is not significant. The expression levels of the PFK gene under $\mathrm{pH}$ control was significantly higher than those of non-pH control at $4 \mathrm{~h}, 8 \mathrm{~h}, 12 \mathrm{~h}$, and $16 \mathrm{~h}$, which were $1.69,1.84,1.32$, and 3.37 times of non-pH control, respectively, indicating a significant drop in $\mathrm{pH}$ inhibited the PFK gene expression.

\section{Discussion}

\section{Effects of molasses concentration on the growth and metabolism of the strain}

As the main component of molasses was sugar, molasses' concentration is directly related to the content of carbohydrates in the medium, the higher its concentration, the higher the osmotic pressure of the extracellular environment to cells. The increase in osmotic pressure would lead to the deterioration of the intracellular microenvironment. It can affect the growth and metabolism of the strain, causing the dehydration and inactivation of protein, which hinder cell cycle and inhibit cell growth (Radmaneshfar et al. 2013). Some studies have found that, with the increase of osmotic stress, the cell will actively regulate osmosis that causes intracellular water outflow, shrinking of cells, and even death (Djelal et al. 2017). Microorganisms would increase energy for maintaining the stability of the intracellular microenvironment (enhancing intracellular stress response and tolerance pathway). These change the metabolic network and regulatory pathways of cells, inhibit the fermentation rate, and change product accumulation (Xu 2010). It was found that the cell growth and pyruvate accumulation rate were inhibited by the increase in osmotic pressure in the pyruvate production (Kamzolova and Morgunov 2016). In arabitol production, when the osmotic pressure was increased, the product's yield would significantly decrease (Koganti et al. 2011). Therefore, combined with the results of growth and metabolism, four low concentrations of molasses, $5^{\circ} \mathrm{Bx}, 7.5^{\circ} \mathrm{Bx}, 10^{\circ} \mathrm{Bx}$, and $20^{\circ} \mathrm{Bx}$, were chosen to investigate the metabolism characteristics of the strain in molasses.

The utilization rate of carbohydrates in different molasses concentrations is also used as an index to select the optimal concentration medium. The results showed that there are enough carbohydrates in the $5{ }^{\circ} \mathrm{Bx}$ medium to ferment the strain. Moreover, the lower the concentration of substrate residual sugar, the higher the fermentation efficiency.

In conclusion, it is feasible to use the engineered strain L. casei E1 to produce ethanol with molasses as substrate conclusion of comparative genomics is verified (Wang et al. 2015). As the carbohydrates utilization rate and the ethanol production yield in $5^{\circ} \mathrm{Bx}$ molasses are the highest, $5^{\circ} \mathrm{Bx}$ is the optimum concentration of molasses for ethanol fermentation. 


\section{The sequence of carbohydrate metabolism of the strain}

The metabolization of carbohydrates by strain E1 is in sequence by inference. This characteristic of strain was showed in all the four low concentrations molasses fermentation (Fig 2), and confirmed by the gene expression results (Fig 7). Agbogbo et al. (2006) used Pichia pastoris (P. stipitis CBS6054) to ferment a mixed medium of glucose and xylose. It was found that the consumption rate of glucose was higher than that of xylose. This indicated that there is a priority order in carbohydrate metabolism of microorganisms.

\section{Effects of oxygen on the ethanol production}

Lactobacillus casei is an aerobic anaerobe like other lactic acid bacteria. Under aerobic conditions, cells proliferated in large amounts and produced lactic acid (Maresca et al. 2019). Reactive Oxygen Species (ROS), present in the environment or metabolized by the strain, can seriously threaten the strain's survival. Some LAB can be subjected to aerobic growth, with a consequent change in the LAB's physiological metabolism, including the reduction of biomass and the change of fermentation product types. ROS can destroy cellular proteins, lipids, and nucleic acids, causing cell aging and death. Therefore, anaerobic culture is the optimum culture condition for ethanol production by the strain.

\section{Effects of $\mathrm{pH}$ on the ethanol production}

Based on the results of acidity control of fermentation broth, it was found that a change in $\mathrm{pH}$ has a significant effect on the growth and metabolism of the strain. This is mainly because fermentation's organic acid will enter the cytoplasm in the form of diffusion and release proton $\mathrm{H}^{+}$after dissociation, subsequently reducing the intracellular environment's $\mathrm{pH}$ value. The continuous acidification of the intracellular environment destroys DNA structures, the denaturation of proteins, and enzymes' inactivation. Moreover, changes in $\mathrm{pH}$ cause the channel proteins, transporters, and signaling pathway proteins on the membrane to lose their normal function that maintains cell-selective permeability, disturbing the balance of sodium-potassium ions inside and outside cells. Ultimately, the physiological activities being affected results in low production efficiency and poor product quality. In the study of succinic acid production by $E$. coli, with the accumulation of succinic acid, the biomass was gradually reduced, and the vitality of the somatic cells was steadily decreased. If the succinic acid is removed in time, the yield of succinic acid can be increased by more than 60\% (Andersson et al. 2010). Roa et al. (2011) found that the lower the $\mathrm{pH}$ value, the lesser the yield of fumaric acid in the Fermentation of Rhizopus oryzae (Roa Engel et al. 2011).

\section{Effects of pH on the gene expression of key enzymes in carbon source metabolism}


Multiple metabolic pathways and enzymes regulate the growth and metabolism of bacterial cells. Under different $\mathrm{pH}$ conditions, the strain's ability to metabolize a specific sugar is affected by the activity of key enzymes and the strain's growth. The amount of enzyme gene expression indicates the demand for this enzyme by the metabolism of the strain. Therefore, the expression level of key enzyme genes in metabolism can reflect the metabolic level of bacteria to a certain extent.

The metabolism of carbohydrates by the strain mainly depends on the catalysis of metabolic-related enzymes. Comparative genomic analysis results revealed that the wild-type strain $L$. casei 12A could degrade nine sugars in cells (Wang et al. 2015). The strain first used glucokinase (GK, EC 2.7.1.2) to degrade glucose to 6-phosphate glucose, which is the common intermediate product and intersection of various metabolic pathways, including glycolysis (EMP pathway), pentose phosphate pathway, and glycogen synthesis and decomposition pathway. Therefore, GK is one of the key enzymes for glucose metabolism. Second, the strain could use phosphofructokinase (PFK, EC 2.7.1.56) to convert fructose to 1, 6-fructose diphosphate (FDP) and then facilitate its entrance into the glycolysis pathway. PFK is one of the key enzymes in fructose metabolism. Third, the strain hydrolyzed sucrose to glucose and fructose using invertase (INV, EC 3.2.1.26). INV is one of the key enzymes for the metabolism of sucrose. Two conditions of $\mathrm{pH}$ control and non-pH control were designed to detect three key enzymes' expression levels. This enabled us to investigate the effect of $\mathrm{pH}$ control on carbon source metabolism.

An in-depth analysis of the three enzymes' gene expression characteristics under two conditions showed that, on the one hand, the expression levels of three enzyme genes in the fermentation broth with regulated $\mathrm{pH}$ were almost more significant than those under the non-pH control state. The amount indicates that the increase in acidity inhibits the synthesis of critical metabolic enzymes (Fig 7). The genes' high expression levels suggested that the number of sugar molecules transported into the cell is large, which is beneficial to cells' rapid activation of metabolic function. Therefore, Fermentation in the medium with a constant $\mathrm{pH}$ of 6.0 is more conducive to the metabolism of the three sugars by the strain; on the other hand, the trend of the gene expression in the two conditions is very similar, indicating that the change in $\mathrm{pH}$ does not change the trend of enzyme gene expression.

In conclusion, this present study proves that $L$. casei, as a potential tool, can be used for bio-ethanol production due to its good tolerance of lower alcohols (Elena, 2015). Through the characteristic analysis of cell growth and metabolism, L. casei El can metabolize sucrose, glucose, and fructose of molasses and synthesize ethanol. In practice, the engineered $L$. casei E1 was grown in different fermentation conditions subjected to the effects of cane molasses concentrations, oxygen, and pH on ethanol production. The genetic strain E1 showed good growth and quick sugar fermentation and yielded high ethanol in cane molasses. By fermenting this bacterium anaerobically at $37^{\circ} \mathrm{C}$ for $36 \mathrm{~h}$ incubation in 5 ${ }^{\circ} \mathrm{BX}$ molasses when the fermenter's $\mathrm{pH}$ was controlled at 6.0 , ethanol yield reached $13.77 \mathrm{~g} / \mathrm{L}$, and carbohydrate utilization percentage was $78.60 \%$.

The expression differences from the GK, INV, and PFK genes between $\mathrm{pH}$-control and non-pH control conditions were detected using RT-qPCR. It could be seen that the genetic strain E1 under pH control 
preferentially fermented glucose and fructose of molasses to ethanol. The non-pH control did not affect the three enzymes' gene expression trends, but an elevated acidity would significantly inhibit the genetically modified strain E1 from metabolizing fructose to ethanol.

\section{Declarations}

\section{Author Contribution}

SW, and BL conceived the study and designed the project. RT and BL conducted experiments. HW, JL and $\mathrm{CL}$ analyzed the data and drafted the manuscript. ML and SEE helped to revise the manuscript. All authors contributed to the article and approved the submitted version.

\section{Funding}

This study was funded by the National Natural Science Youth Foundation of China (No. 31801518), the "Young Talents" Project of Northeast Agricultural University (18QC52), the Natural Science Foundation of Heilongjiang Province (YQ2020C013) and the Academic Backbone Plan of Northeast Agricultural University (No. 19YJXG10).

\section{Acknowledgment}

We thank James Steele's Lab, Department of Food Science, University of Wisconsin-

Madison (Madison, WI, USA) for providing L. casei E1 used for this study. And we also thank our industrial partner, Shandong Yuwang Ecological Food Industry Co., Ltd. (Dezhou, Shandong, China), for supply of the sugarcane malasses.

\section{Conflict of Interest}

The authors declare that they have no conflict of interest.

\section{Ethical approval}

This article does not contain any studies with animals performed by any of the authors.

\section{Informed consent}

Informed consent was obtained from all individual participants included in the study. 


\section{Data Availability Statements}

The authors declare that all the data supporting the findings of this study are available within the article.

\section{References}

1. Agbogbo KF, Coward-Kelly G, Torry-Smith M, Wenger KS (2006) Fermentation of glucose/xylose mixtures using Pichia stipitis. Process Biochem 41:2333-2336. doi: 10.1016/j.procbio.2006.05.004

2. Andersson C, Petrova E, Berglund K, Rova U (2010) Maintaining high anaerobic succinic acid productivity by product removal. Bioproc Biosyst Eng 33:711-718. doi: 10.1007/s00449-009-0393-y

3. Baki AS, Bande YM, Bello A (2020) Comparative Studies on Bioethanol Production from Cassava Peels using Saccromyces Cerevisae and Zymomonas Mobilis. Open Access J Biomed Eng Biosci 3:373-378. doi: 10.32474/OAJBEB.2020.03.000174

4. Blanco-Míguez A, Fdez-Riverola F, Sánchez B, Lourenço A (2019) Resources and tools for the highthroughput, multi-omic study of intestinal microbiota. Brief Bioinform 20:1032-1056. doi: 10.1093/bib/bbx156

5. Britz TJ, Tracey RP (1990) The combination effect of $\mathrm{pH}, \mathrm{SO}_{2}$, ethanol and temperature on the growth of Leuconostoc oenos. J Bacteriol 68:23-31. doi: 10.1111/j.1365-2672.1990.tb02544.x

6. Bubnová M, Zemančíková J, Sychrová H (2014) Osmotolerant yeast species differ in basic physiological parameters and in tolerance of non-osmotic stresses. Yeast 31:309-21. doi: 10.1002/yea.3024

7. Cai H, Rodríguez BT, Zhang W, Broadbent JR, Steele JL (2007) Genotypic and phenotypic characterization of Lactobacillus casei strains isolated from different ecological niches suggests frequent recombination and niche specificity. Microbiology 153:2655-2665. doi: $10.1099 / \mathrm{mic} .0 .2007 / 006452-0$

8. Davis CR, Wibowo D, Fleet GH, Lee TH (1988) Properties of wine lactic acid bacteria: their potential enological significance. Am J Enol Viticult 39(2):137-142. doi: 10.1007/BF01042707

9. Dittrich CR, Vadali RV, Bennett GN, San KY (2005) Redistribution of metabolic fluxes in the central aerobic metabolic pathway of E. coli mutant strains with deletion of the ackA-pta and poxB pathways for the synthesis of isoamyl acetate. Biotechnol Prog 21:627-31. doi: 10.1021/bp049730r

10. Djelal H, Chniti S, Jemni M, Weill A, Sayed W, Amrane A (2017) Identification of strain isolated from dates (Phœnix dactylifera L.) for enhancing very high gravity ethanol production. Environ Sci Pollut $R$ 24:9886-9894. doi: 10.1007/s11356-016-8018-x

11. Dziugan P, Balcerek M, Pielech-Przybylska K, Patelski P (2013) Evaluation of the fermentation of high gravity thick sugar beet juice worts for efficient bioethanol production. Biotechnol Biofuels 6:158. doi: 10.1186/1754-6834-6-158

12. Edwards CG, Jensen KA (1992) Occurrence and characterization of lactic acid bacteria from Washington State wines: Pediococcus spp.. Am J Enol Viticult 43:233-238. doi: 10.1097/00008390- 
199205000-00010

13. G-Alegría E, López I, Ruiz JI, Sáenz J, Fernández E, Zarazagaet M, Dizyal M, Torres C, Ruiz-Larrea F (2004) High tolerance of wild Lactobacillus plantarum and Oenococcus oeni strains to lyophilisation and stress environmental conditions of acid pH and ethanol. FEMS Microbiol Lett 230:53-61. doi: $\underline{10.1016 / \text { S0378-1097(03) } 00854-1}$

14. Gold RS, Meagher MM, Hutkins R, Conway T (1992) Ethanol tolerance and carbohydrate metabolism in Lactobacilli. J Ind Microbiol Biot 10:45-54. doi: 10.1007/BF01583633

15. Kamzolova SV, Morgunov IG (2016) Biosynthesis of pyruvic acid from glucose by Blastobotrys adeninivorans. Appl Microbiol Biot 100:7689-7697. doi: 10.1007/s00253-016-7618-1

16. Koganti S, Kuo TM, Kurtzman CP, Smith N, Ju L (2011) Production of arabitol from glycerol: strain screening and study of factors affecting production yield. Appl Microbiol Biot 90:257-267. doi: 10.1007/s00253-010-3015-3

17. Koryszewska-Bagińska A, Gawor J, Nowak A, Grynberg M, Aleksandrzak-Piekarczyk T (2019) Comparative genomics and functional analysis of a highly adhesive dairy Lactobacillus paracasei subsp. paracasei IBB3423 strain. Appl Microbiol Biotechnol 103:7617-7634. doi: $10.1007 / \mathrm{s} 00253-019-10010-1$

18. Liu S, Bischoff KM, Leathers TD, Qureshi N, Rich JO, Hughes SR (2012) Adaptation of lactic acid bacteria to butanol. Biocatal Agric Biotechnol 1:57-61. doi: 10.1016/j.bcab.2011.08.008

19. Livak KJ, Schmittgen TD (2001) Analysis of relative gene expression data using real-time quantitative PCR and the $2^{-\triangle \Delta C t}$ method. Methods 25:402-408. doi: $10.1006 /$ meth.2001.1262

20. London J, Chace NM (1979) Pentitol metabolism in Lactobacillus casei. J Bacteriol 140:949-954. doi: 10.1128/JB.140.3.949-954.1979

21. Maresca D, Filippis FD, Robertiello A, Mauriello G (2019) Metabolic Profiling and Cold-Starvation Stress Response of Oxygen-Tolerant Lactobacillus gasseri Strains Cultured in Batch Bioreactor. Microorganisms 7:200. doi: 10.3390/microorganisms 7070200

22. Matsuoka Y, Kurata $\mathrm{H}$ (2017) Modeling and simulation of the redox regulation of the metabolism in Escherichia coli at different oxygen concentrations. Biotechnol Biofuels 10:183. doi: 10.1186/s13068-017-0867-0

23. McAuliffe O, Kilcawley K, Stefanovic E (2019) Symposium review: Genomic investigations of flavor formation by dairy microbiota. J Dairy Sci 102:909-922. doi: 10.3168/jds.2018-15385

24. Meng Q, Yang W, Men M, Bello A, Xu X, Xu B, Deng L, Jiang X, Sheng S, Wu X, Han Y, Zhu H (2019) Microbial Community Succession and Response to Environmental Variables During Cow Manure and Corn Straw Composting. Front Microbiol 10:529. doi: 10.3389/fmicb.2019.00529

25. Radmaneshfar E, Kaloriti D, Gustin CM, Gow NAR, Brown AJP, Grebogi C, Romano MC, Thiel M (2013) From START to FINISH: The influence of osmotic stress on the cell Cycle. Plos One 8:e68067. doi: 10.1371/journal.pone.0068067 
26. Roa Engel CA, van Gulik WM, Marang L, van der Wielen, Straathof AJJ (2011) Development of a low $\mathrm{pH}$ fermentation strategy for fumaric acid production by Rhizopusoryzae. Enzyme Microb Tech 48:39-47区 doi: 10.1016/j.enzmictec.2010.09.001

27. Suzuki S, Fujita K, Maeno S, Shiwa Y, Kajikawa A (2020) PCR-based screening, isolation, and partial characterization of motile lactobacilli from various animal feces. BMC Microbiol 20:142. doi: 10.1186/s12866-020-01830-7

28. Takashi K, Sarengaole, Hajime T, Bon K (2016) Alcohol-brewing properties of acid- and bile-tolerant yeasts co-cultured with lactic acid bacteria isolated from traditional handmade domestic dairy products from Inner Mongolia. LWT-Food Sci Technol 65(1):62-69. doi: 10.1016/j.Iwt.2015.07.065

29. Tanawut N, Poonsuk P, Chonticha L, Supalak S, Pongsak N (2020) Bioconversion of oil palm trunk residues hydrolyzed by rnzymes from newly isolated fungi and use for ethanol and acetic acid production under two-stage and simultaneous fermentation. Waste and Biomass Valori 11:13331347. doi: 10.1007/s12649-019-00678-x

30. Vinay-Lara E, Wang S, Bai L, Phrommao E, Broadbent JR, Steele JL (2016) Lactobacillus casei as a biocatalyst for biofuel production. J Ind Microbiol Biotechnol 43:1205-1213. doi: 10.1007/s10295$\underline{016-1797-8}$

31. Virgilio S, Cupertino FB, Ambrosio DL, Bertolini MC (2017) Regulation of the reserve carbohydrate metabolism by alkaline $\mathrm{pH}$ and calcium in Neurospora crassa reveals a possible crossregulation of both signaling pathways. BMC Genomics 18:457. doi: 10.1186/s12864-017-3832-1

32. Wang S, LiangG HZ, Jia CF, Zhang BL (2015) Comparative genomics analysis of carbon metabolism of Lactobacillus casei 12A. Microbiol China 42: 315-324. doi: 10.13344/j.microbiol.china. 140756

33. Welker DL, Hughes JoE, Steele JL, Broadbent JR (2015) High efficiency electrotransformation of Lactobacillus casei. FEMS Microbiol Lett 362(2):1-6. doi: 10.1093/femsle/fnu033

34. Wu R, Chen D, Cao S, Lu Z, Huang J, Lu Q, Chen Y, Chen X, Guan N, Wei Y and Huang R (2020) Enhanced ethanol production from sugarcane molasses by industrially engineered Saccharomyces cerevisiaevia replacement of the PHO4 gene. RSC Adv 10:2267-2276. doi: 10.1039/C9RA08673K

35. Wushke S, Spicer V, Zhang XL, Fristensky B, Krokhin OV, Levin DB, Cicek N, Sparling R (2017) Understanding aerobic/anaerobic metabolism in Caldibacillus debilis through a comparison with model organisms. Syst Appl Microbiol 40:245-253. doi: 10.1016/j.sygapm.2017.03.004

36. Xu S (2010) Analysis of the Physiological Mechanisms of Osmotic Stress Tolerance in Torulopsis Glabrata. Doctoral dissertation of Jiangnan University.

37. Xin Y, Guo T, Mu Y, Kong J (2018) Coupling the recombineering to Cre-lox system enables simplified large-scale genome deletion in Lactobacillus casei. Microb Cell Fact 17:21. doi: 10.1186/s12934018-0872-4

38. Yao Y, Lv Z, Lin X, Ren M, Zhang B (2011) Application of Leuconostoc mesenteroides subsp. dextranicum in the production of cider. China Brew 227:48-51. doi: 10.3969/j.issn.0254$\underline{5071.2011 .02 .014}$ 


\section{Tables}

Table 1

Carbohydrate utilization ratio and ethanol production ratio in low concentrations of molasses for $72 \mathrm{~h}$

\begin{tabular}{|llll|}
\hline Concentrations & Carbohydrate utilization ratio $(\mathrm{w} / \mathrm{w} \%)$ & $\begin{array}{l}\text { Ethanol production } \\
\text { ratio }(\mathbf{w} / \mathbf{w} \%)\end{array}$ & $\begin{array}{l}\text { Ethanol: Lactate } \\
(\mathrm{mmol} / \mathrm{L}: \mathrm{mmol} / \mathrm{L})\end{array}$ \\
\hline $\mathbf{5}^{\circ} \mathrm{BX}$ & 75.2 & 35.8 & 2.0 \\
\hline $\mathbf{7 . 5 ^ { \circ } \mathrm { BX }}$ & 56.5 & 38.0 & 1.8 \\
\hline $\mathbf{1 0 ^ { \circ } \mathrm { BX }}$ & 38.6 & 35.7 & 1.7 \\
\hline $\mathbf{2} \mathbf{0}^{\circ} \mathrm{BX}$ & 25.6 & 24.6 & 0.6 \\
\hline
\end{tabular}

Table 2

Carbohydrate metabolism in four low concentrations of cane molasses

\begin{tabular}{|c|c|c|c|c|c|c|c|}
\hline \multicolumn{8}{|c|}{ Concentrations of fermentation broth } \\
\hline \multicolumn{2}{|l|}{$5^{\circ} \mathrm{BX}$} & \multicolumn{2}{|l|}{$7.5^{\circ} \mathrm{BX}$} & \multicolumn{2}{|l|}{$10^{\circ} \mathrm{BX}$} & \multicolumn{2}{|l|}{$20^{\circ} \mathrm{BX}$} \\
\hline $\mathrm{Oh}$ & $72 \mathrm{~h}$ & Oh & $72 \mathrm{~h}$ & Oh & $72 \mathrm{~h}$ & Oh & $72 \mathrm{~h}$ \\
\hline $\begin{array}{l}34.52 \pm \\
0.26\end{array}$ & $\begin{array}{l}11.03 \pm \\
0.41\end{array}$ & $\begin{array}{l}42.41 \pm \\
1.35\end{array}$ & $\begin{array}{l}24.68 \pm \\
0.33\end{array}$ & $\begin{array}{l}56.79 \pm \\
1.04\end{array}$ & $\begin{array}{l}47.92 \pm \\
0.48\end{array}$ & $\begin{array}{l}74.18 \pm \\
0.89\end{array}$ & $\begin{array}{l}71.85 \pm \\
1.13\end{array}$ \\
\hline $\begin{array}{l}3.57 \pm \\
0.04\end{array}$ & $\begin{array}{l}0.02 \pm \\
0.01\end{array}$ & $\begin{array}{l}4.67 \pm \\
0.07\end{array}$ & $\begin{array}{l}0.34 \pm \\
0.12\end{array}$ & $\begin{array}{l}6.50 \pm \\
0.32\end{array}$ & $\begin{array}{l}0.74 \pm \\
0.05\end{array}$ & $\begin{array}{l}19.26 \pm \\
0.22\end{array}$ & $\begin{array}{l}7.16 \pm \\
0.08\end{array}$ \\
\hline $\begin{array}{l}9.37 \pm \\
0.51\end{array}$ & $\begin{array}{l}0.73 \pm \\
0.02\end{array}$ & $\begin{array}{l}12.64 \pm \\
0.03\end{array}$ & $\begin{array}{l}0.93 \pm \\
0.05\end{array}$ & $\begin{array}{l}17.69 \pm \\
0.62\end{array}$ & $\begin{array}{l}1.10 \pm \\
0.04\end{array}$ & $\begin{array}{l}31.58 \pm \\
0.09\end{array}$ & $\begin{array}{l}13.99 \pm \\
0.21\end{array}$ \\
\hline $\begin{array}{l}0.57 \pm \\
0.03\end{array}$ & $\begin{array}{l}1.59 \pm \\
0.11\end{array}$ & $\begin{array}{l}0.69 \pm \\
0.03\end{array}$ & $\begin{array}{l}0.70 \pm \\
0.04\end{array}$ & $\begin{array}{l}0.94 \pm \\
0.41\end{array}$ & $\begin{array}{l}0.99 \pm \\
0.02\end{array}$ & $\begin{array}{l}17.86 \pm \\
0.15\end{array}$ & $\begin{array}{l}12.73 \pm \\
0.17\end{array}$ \\
\hline $\begin{array}{l}0.47 \pm \\
0.02\end{array}$ & $\begin{array}{l}10.04 \pm \\
0.19\end{array}$ & $\begin{array}{l}0.55 \pm \\
0.01\end{array}$ & $\begin{array}{l}11.30 \pm \\
0.11\end{array}$ & $\begin{array}{l}0.13 \pm \\
0.03\end{array}$ & $\begin{array}{l}9.96 \pm \\
0.10\end{array}$ & $\begin{array}{l}11.70 \pm \\
0.01\end{array}$ & $\begin{array}{l}21.63 \pm \\
0.07\end{array}$ \\
\hline 0.00 & $\begin{array}{l}12.76 \pm \\
0.27\end{array}$ & 0.00 & $\begin{array}{l}12.83 \pm \\
0.30\end{array}$ & 0.00 & $\begin{array}{l}11.13 \pm \\
0.06\end{array}$ & 0.00 & $\begin{array}{l}7.87 \pm \\
0.01\end{array}$ \\
\hline
\end{tabular}


Table 3

Effect of $\mathrm{pH}$ on carbohydrate metabolism

\begin{tabular}{|c|c|c|c|c|}
\hline \multirow[t]{2}{*}{ Time (h) } & \multicolumn{2}{|c|}{ Residual carbohydrate content $(\mathrm{g} / \mathrm{L})$} & \multicolumn{2}{|c|}{ Ethanol yield (g/L) } \\
\hline & $\mathrm{pH}$ control & non-pH control & pH control & non-pH control \\
\hline 0 & $60.83 \pm 0.79$ & $61.42 \pm 0.29$ & 0 & 0 \\
\hline 36 & $13.03 \pm 0.52$ & $20.63 \pm 0.06$ & $13.77 \pm 0.24$ & $10.62 \pm 0.17$ \\
\hline 60 & 0 & $10.46 \pm 0.15$ & $14.85 \pm 0.08$ & $12.15 \pm 0.35$ \\
\hline
\end{tabular}

Figures

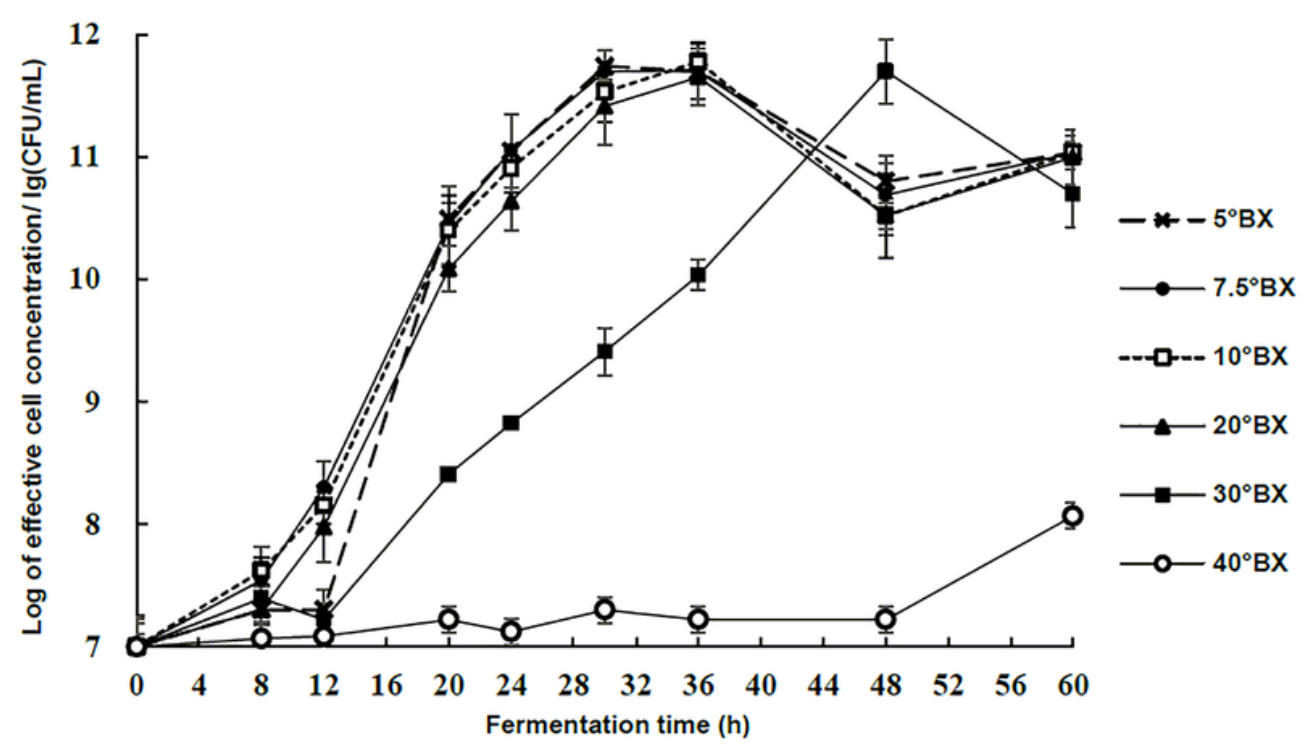

Figure 1

See the Supplemental Files section for the complete figure caption 

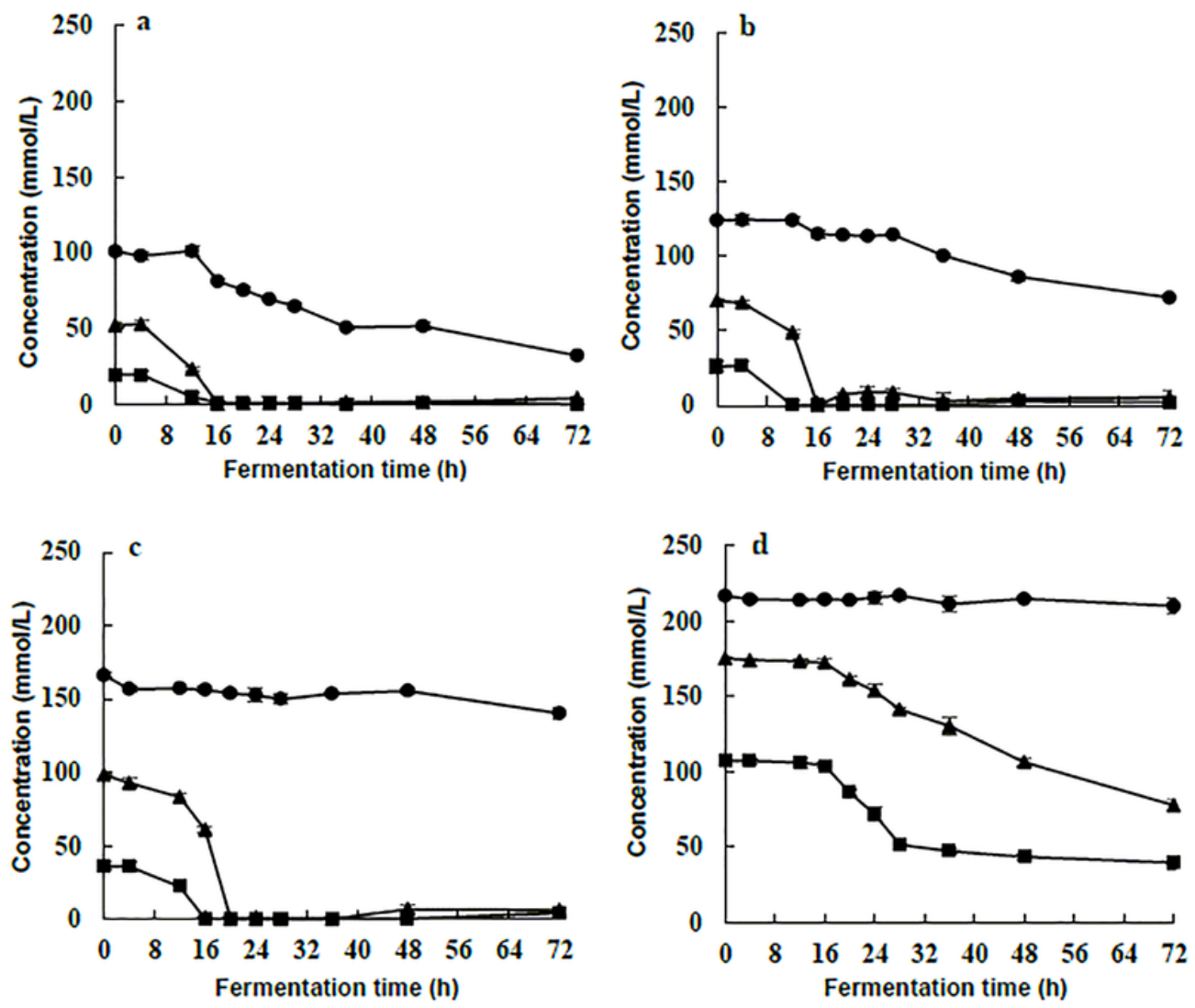

Figure 2

See the Supplemental Files section for the complete figure caption 

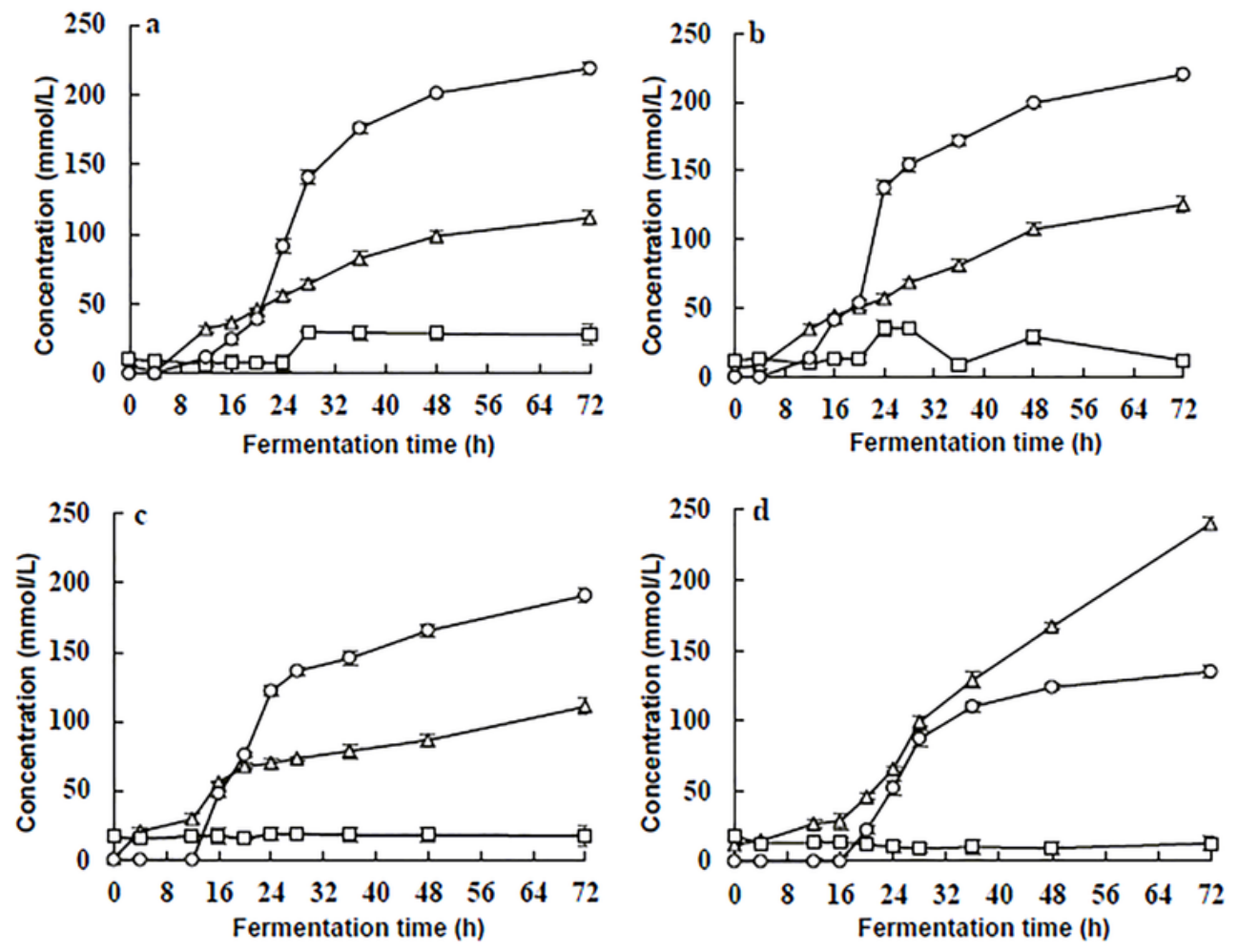

\section{Figure 3}

See the Supplemental Files section for the complete figure caption
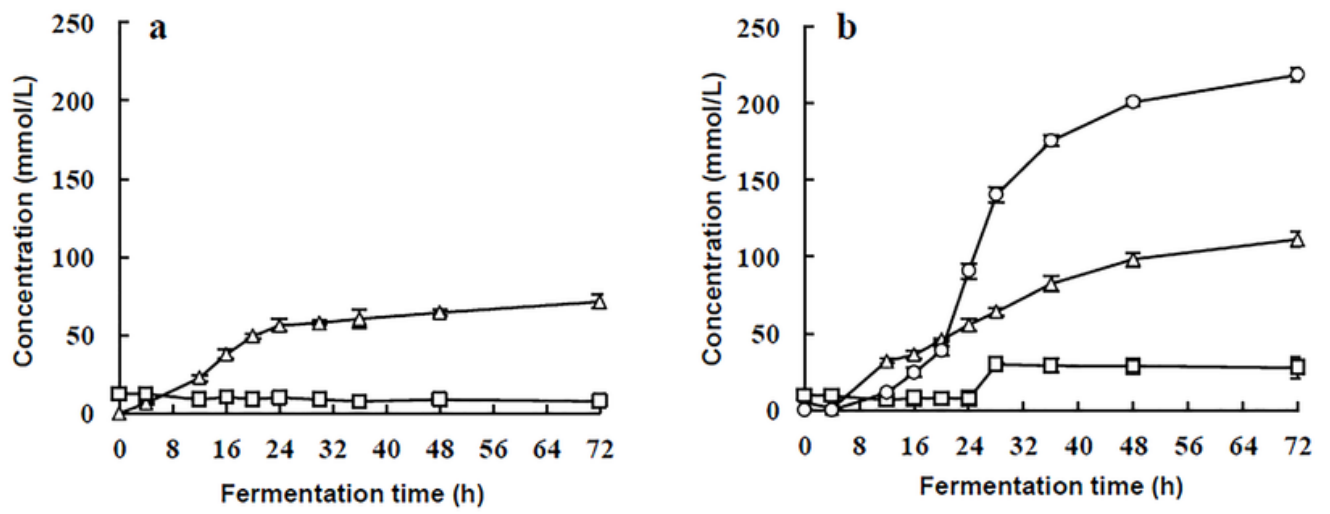

Figure 4

See the Supplemental Files section for the complete figure caption 


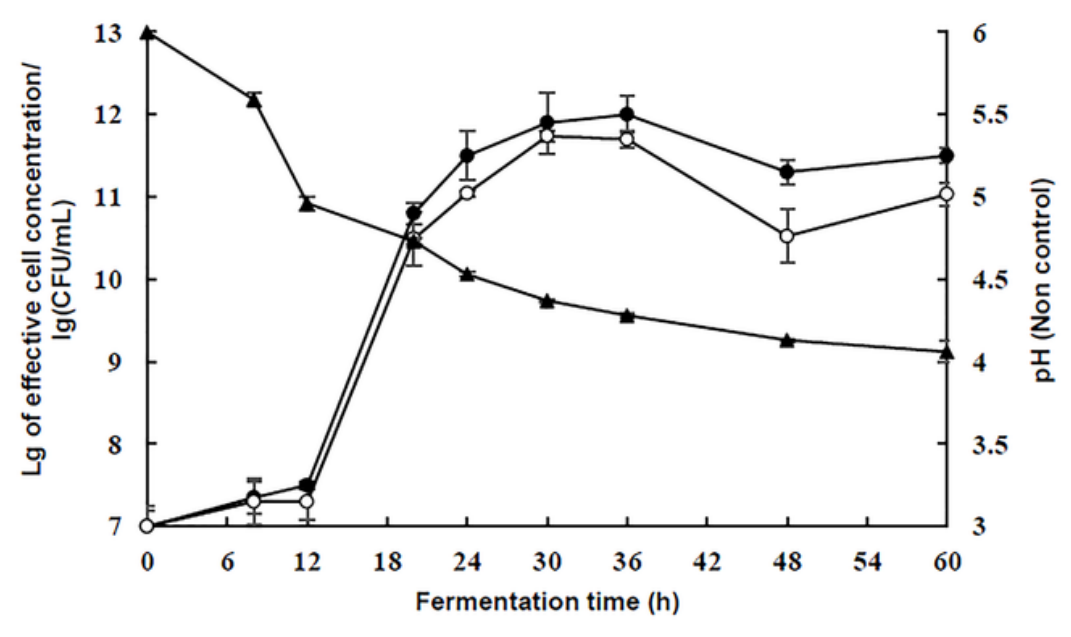

Figure 5

See the Supplemental Files section for the complete figure caption
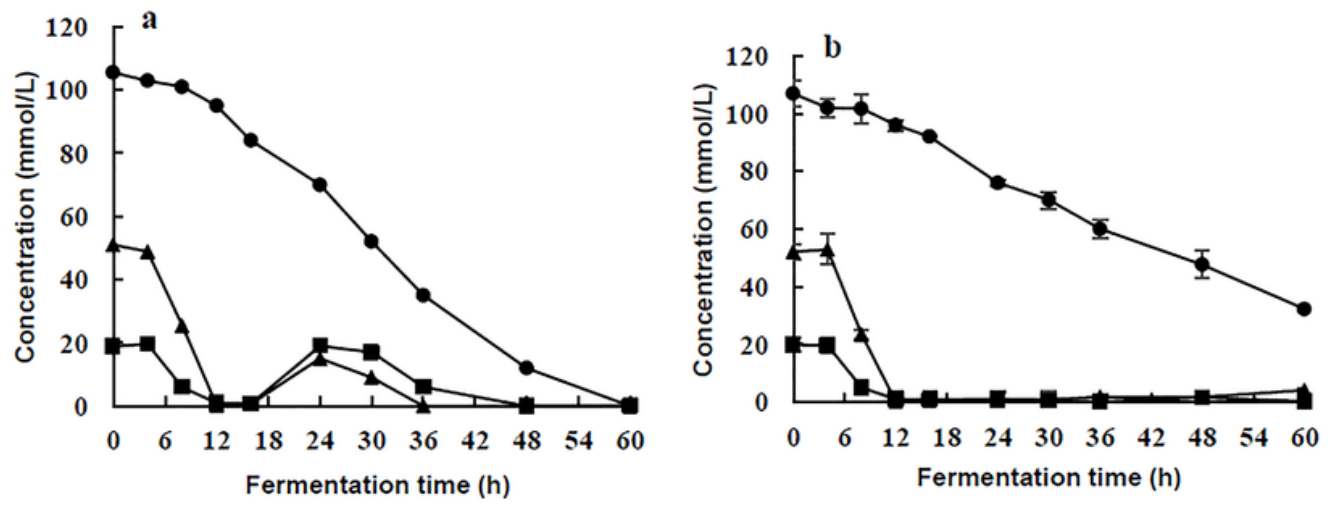

Figure 6

See the Supplemental Files section for the complete figure caption 

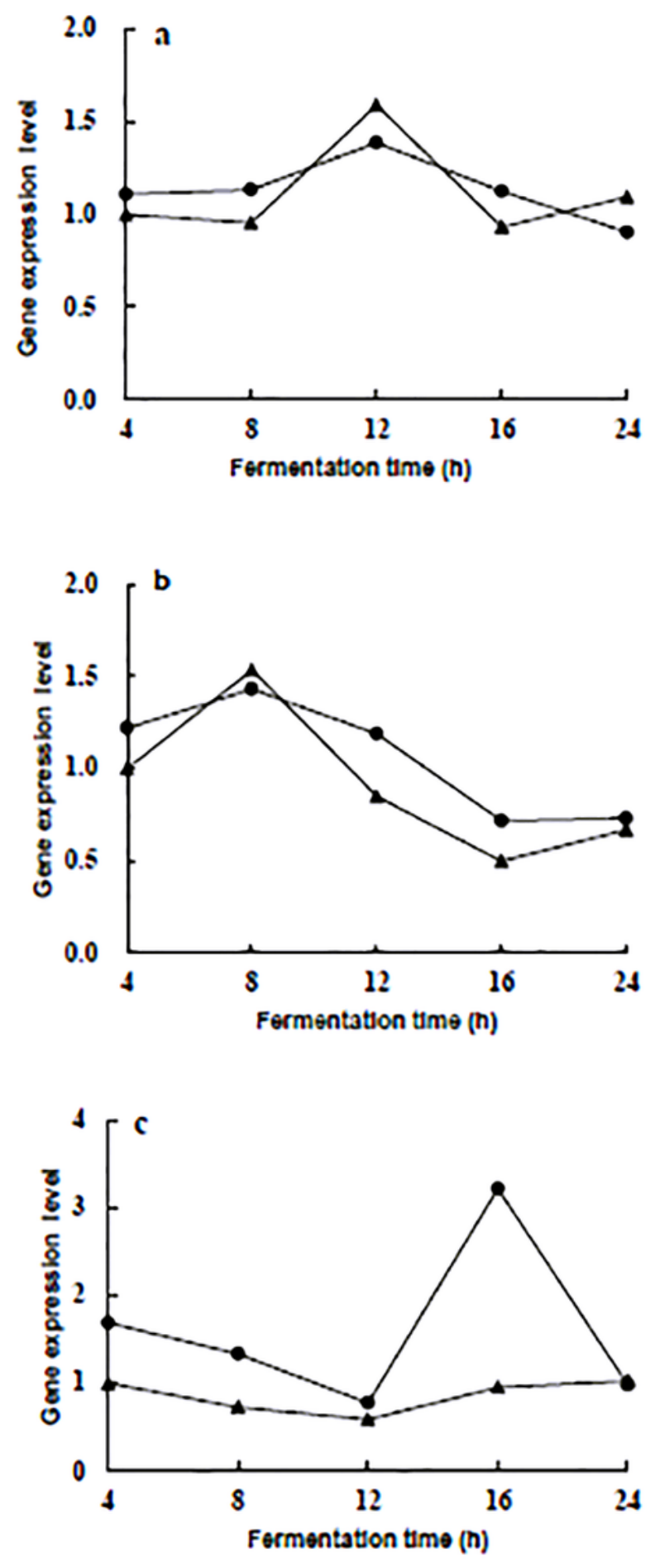

Figure 7

See the Supplemental Files section for the complete figure caption 

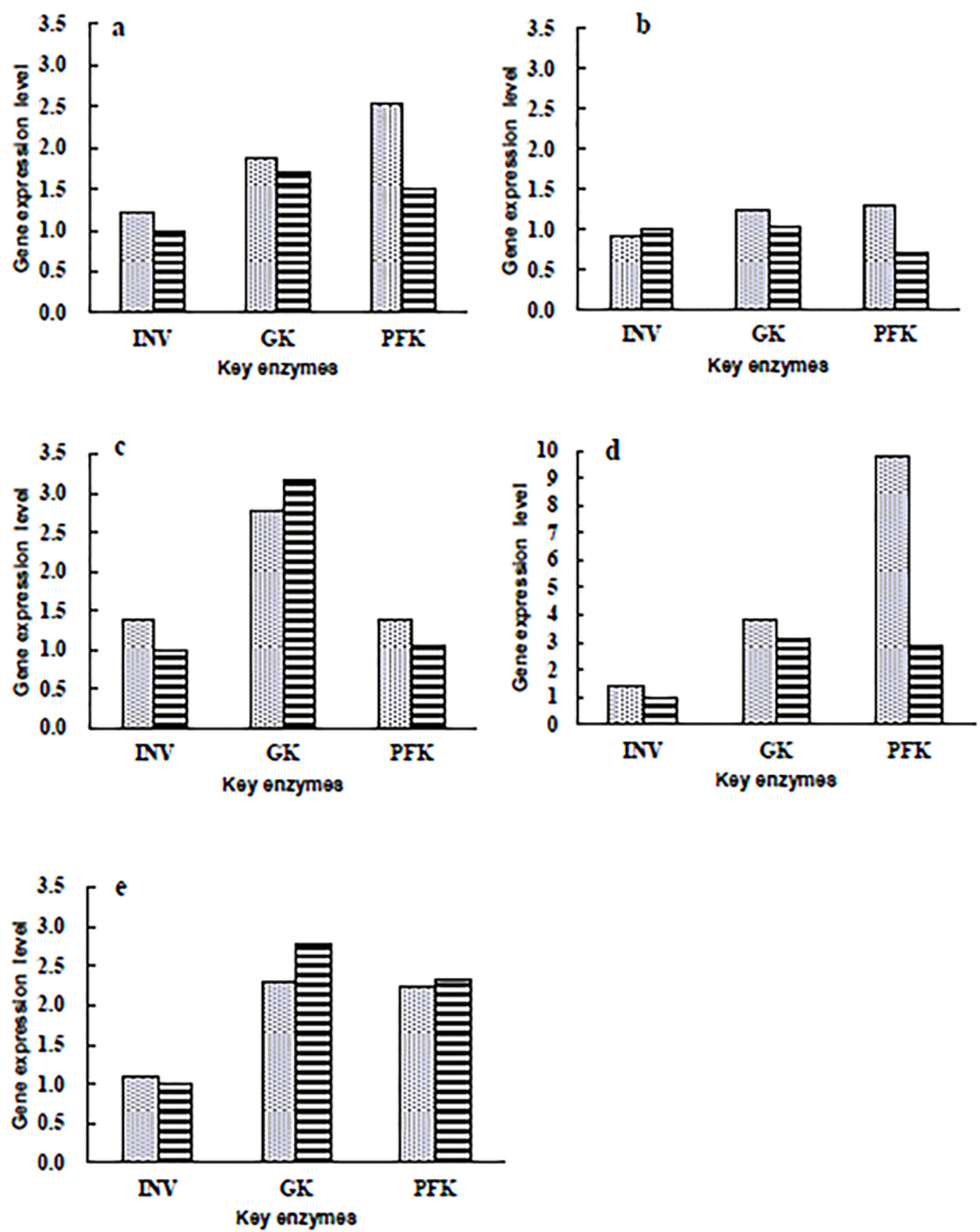

Figure 8

See the Supplemental Files section for the complete figure caption

\section{Supplementary Files}

This is a list of supplementary files associated with this preprint. Click to download. 
- GraphicalAbstracts.tif

- FigureCaptions.docx 